\title{
SEISMIC AND WIND VULNERABILITY ASSESSMENT FOR THE GAR-13 GLOBAL RISK MODEL
}

\author{
Luis E. Yamin ${ }^{1}$, Alvaro I. Hurtado ${ }^{1}$, Alex H. Barbat ${ }^{2}$, Omar D. Cardona ${ }^{3}$
}

\begin{abstract}
A general methodology to evaluate vulnerability functions suitable for a probabilistic global risk assessment is proposed. The methodology is partially based in the methodological approach of the Multihazard Loss Estimation Methodology (Hazus) developed by the Federal Emergency Management Agency (FEMA). The vulnerability assessment process considers the resolution, information and limitations established for both the hazard and exposure models adopted. Seismic and wind vulnerability functions are estimated for each one of the building classes defined in typical global exposure databases. They consider possible variations according to the design level in different regions of the world which accounts for variations of the expected quality of construction and the design code compliance level. In addition, a consistent, expert opinion based methodology is proposed in order to assign particular vulnerability functions to building classes according to the development level of each country, the city complexity and the hazard level of the region. The proposed set of vulnerability functions and the assignment procedure were used for the probabilistic global risk assessment made in the framework of the UNISDR's Global Assessment Report on Disaster Risk Reduction, GAR 2013. Recommendations for the refinement of the methodological approach are included for future global or scaled regional risk assessments.
\end{abstract}

Keywords: vulnerability functions, risk analysis, economic losses.

\section{Introduction}

The global risk assessment made in the framework of the UNISDR's Global Assessment Report on Disaster Risk Reduction, GAR 2013 [1,2] uses a set of vulnerability curves suitable for a probabilistic global risk assessment. These functions establish the relation between the intensity of the hazard event and the mean damage ratio, MDR, of the particular building class which it represents. One set of particular functions has been estimated for each one of the building classes defined in the exposure database in order to consider variations in the design level. The loss probability distribution function for each building class can then be estimated using both the MDR and its corresponding variance for each hazard intensity.

\footnotetext{
${ }^{1}$ Departamento de Ingeniería Civil y Ambiental, Universidad de los Andes, Bogotá, Colombia; lyamin@uniandes.edu.co, ai.hurtado77@uniandes.edu.co

${ }^{2}$ Centro Internacional de Método Numéricos en Ingeniería, CIMNE, Universidad Politécnica de Cataluña, España; barbat@cimne.upc.edu

${ }^{3}$ Instituto de Estudios Ambientales, IDEA, Universidad Nacional de Colombia - Sede Manizales, Colombia; odcardonaa@unal.edu.co
}

International Journal of Disaster Risk Reduction10(2014)452-460

http://dx.doi.org/10.1016/j.ijdrr.2014.05.007 
Building classes in the exposure database correspond to general building classifications proposed in references [3] and [4] complemented with particular local information in several countries worldwide. The vulnerability representation of typical building classes shall consider the expected effects of the construction quality and the design code compliance level for different city categories of each country. Therefore modifications of the characteristic vulnerability functions are proposed to consider those factors.

The vulnerability assessment process considers the resolution, information and limitations established for both the hazard and exposure models adopted for the global risk assessment. The intensity parameter for the seismic hazard assessment corresponds to the elastic spectral acceleration. The one for cyclonic extreme wind corresponds to the maximum wind velocity sustained for five seconds at a reference height of 10 meters above the ground level on a relatively flat terrain. On the other hand, the Global Exposure Database (GED) for the global risk assessment was developed at a global scale with a resolution at urban areas of $5 \mathrm{~km} \times 5 \mathrm{~km}$ cells. Exposure values were assigned using the country capital stock and the geographical distribution of the population [5]. Representative building classes are assigned at each location taking into consideration dominant building use groups (residential, commercial, industrial, and institutional for both private and public sectors), [6].

This paper proposes a methodological approach to develop consistent seismic and wind vulnerability functions which adequately represent the expected losses for different building classes considering variations associated with the expected quality of construction and code level compliance at a regional scale. A methodological approach partially based on the Hazus probabilistic risk assessment model was adopted [7]. Simultaneously, a consistent methodology to assign such vulnerability functions to particular building classes according to the development level of each country, the city complexity and the hazard level is proposed. Illustrative examples of the resulting seismic and wind vulnerability functions as well as the results of the vulnerability function assignment process are presented. The vulnerability functions developed in this paper are to be used under the risk assessment methodology adopted by the Central America Probabilistic Risk Assessment initiative, the CAPRA [8]. Additional related information can be found in references $[1,2,9,10,11,12,13]$.

\section{Methodology}

\subsection{General approach for vulnerability assessment}

Different approaches have been proposed to consider the physical vulnerability in the development of probabilistic risk assessment models $[14,15,16,17]$. Seismic fragility functions estimates the probability of reaching or exceeding a specific limit state given hazard intensity. Limit states for damage are usually defined in qualitative and descriptive terms (e.g. S: slight, M: moderate, E: extensive and C: collapse). On the other hand, probabilistic seismic vulnerability functions relate a given risk figure, as for example the expected economic loss or the MDR, to a hazard intensity parameter. 
Fig. 1. Typical representation of fragility (a) and vulnerability (b) formulations

The formulation for the fragility curves requires the consideration of $N$ identified damage states, $d s$, for a structural system. Then the probability of reaching or exceeding the $i^{\text {th }}$ damage state $\mathrm{P}_{\mathrm{i}}$, given a hazard intensity $S$ is:

$\mathrm{P}_{\mathrm{i}}=\operatorname{Pr}\left(D S \geq d s_{i} \mid S\right)$

where $D S$ is a damage random variable on the damage state vector $\left\{d s_{0}, d s_{1}, \ldots, d s_{N}\right\}$. According to [7], $\mathrm{P}_{\mathrm{i}}$ can be estimated using the following function:

$\mathrm{P}_{\mathrm{i}}=\Phi \llbracket \frac{1}{\beta_{d s_{i}}} \ln \left(\frac{s}{\overline{\bar{s}_{d s_{i}}}}\right) \rrbracket$

where $\bar{S}_{d s_{i}}$ is the median value of the hazard intensity parameter at which the building reaches the threshold of damage state, $d s_{i} ; \beta_{d s_{i}}$ is the standard deviation of the natural logarithm of the hazard intensity parameter for damages state, $d s i$, and $\Phi$ is the standard normal cumulative distribution function.

The formulation of vulnerability functions requires the definition of the loss $L$ as a random variable. In that case the vulnerability function describes the variation of the loss statistical moments (mean and variance) for different values of the hazard intensity. The vulnerability function provides all the necessary information to calculate the probability of reaching or exceeding a loss value, given the hazard intensity. Loss is defined using numerical scales instead of qualitative scales as for damage states (for example the ratio of repair cost to the component replacement value, also known as the mean damage ratio, MDR), which allows its direct use in probabilistic risk and loss calculations. The probability of reaching or exceeding a loss value is calculated as follows:

$\operatorname{Pr}(L \geq l \mid S)=\int_{l}^{\infty} p_{L \mid S}(L) d L$

where $l$ is a loss value in the random variable $L$ dominium, $S$ is the hazard intensity demand and $p_{L \mid S}(L)$ is the loss probability distribution function usually assumed as Beta.

It is possible to obtain the vulnerability function once the fragility formulation is available [2]. For this, a repair cost $L_{i}$ must be assigned to each one of the defined damage states, $d s_{i}$. Therefore, the loss statistical moments given a certain hazard intensity can be calculated as follows:

$E(L \mid S)=\sum_{i=0}^{N} L_{i} \operatorname{Pr}\left(D S=d s_{i} \mid S\right)$

$S D^{2}(L \mid S)=\sum_{i=0}^{N}\left(L_{i}-E(L \mid S)\right)^{2} \operatorname{Pr}\left(D S=d s_{i} \mid S\right)$

where $E(L \mid S)$ is the loss mean and $S D(L \mid S)$ is the loss standard deviation given a hazard demand $S$, and $\operatorname{Pr}\left(D S=d s_{i} \mid S\right)$ is the discrete probability of reaching a damage state $d s_{i}$. These equations correspond to the MDR of the vulnerability function and its corresponding variance [18]. 
In order to consider variables such as the quality of construction and code compliance level, different design levels are considered according to Table 1.

\section{Table 1}

Design levels for vulnerability assessment

\subsection{Seismic vulnerability assessment}

The seismic vulnerability functions developed in this paper are based on the same methodological approach of reference [7] modified and complemented with some considerations and parameters proposed in [19]. The elastic spectral acceleration for 5\% damping at the estimated structural vibration period of each representative building class is selected as the controlling hazard intensity parameter. Ref. [20] is used to transform maximum roof drift ratio to elastic spectral acceleration $S_{a}$ as follows:

$S_{a}=\frac{4 \pi^{2} \delta H}{g \beta_{1} \beta_{2} \beta_{3} \beta_{4} T_{e}^{2}}$

where:

$\delta=$ roof drift ratio

$g=$ gravity acceleration

$\beta_{I}=$ participation factor ratio between the maximum roof displacement and the spectral displacement

$\beta_{2}=$ participation factor ratio between the maximum IDR and the roof drift ratio

$\beta_{3}=$ inelastic displacement ratio

$\beta_{4}=$ inelastic ductility ratio

$T_{e}=$ fundamental vibration period

$H=$ total building height

The methodology comprises the main steps described in Fig. 2 which have to be applied for each design level under consideration.

Fig. 2. Main steps to generate vulnerability functions

\subsection{Wind vulnerability assessment}

For cyclonic extreme wind vulnerability assessment the maximum wind velocities sustained for 5 seconds at a reference height of 10 meters above the ground level on a relatively flat terrain is selected as the controlling intensity parameter. 
Given that, for a global risk model, the exposure data resolution is very limited and does not allow the level of detail required for considering all the variables necessary to estimate the wind damage for different hazard intensities, representative wind vulnerability functions have been assigned to the building classes, using the information available in [21]. Furthermore, in order to complete the required catalog of wind vulnerability functions for global building classes, expert opinions have been used to propose the parameters required to generate vulnerability functions for building classes predominant in developing countries in order to complement the already proposed functions.

The vulnerability functions for cyclonic wind are formulated using a beta distribution function, as it was originally proposed in reference [22] to represent damage factors as a function of the seismic intensity parameters:

$E[\beta]=E\left[1-0.5^{\left(\frac{V}{\gamma}\right)^{\rho}}\right]$

where $E[\beta]$ is the expected mean damage ratio value expressed as a percentage, $V$ is the hazard intensity, $\gamma$ is the intensity for the mean damage ratio $E[\beta]=0.50$ and $\rho$ is the curvature parameter.

\subsection{Building classes}

Vulnerability functions are developed for the different design levels of a group of selected building classes in order to develop a complete catalog of functions necessary in the risk assessment. The building classes include those most commonly used in developed as well as in developing countries, like those included in references [3, 4].

The building typologies for vulnerability classification were defined with some modifications with respect to the original ones $[3,4]$ because of the following reasons:

- The design level is considered in the present approach as an additional qualifier to each one of the building classes. In references $[3,4]$ the design level usually generated new building classes.

- The building typologies proposed in these references were originally defined using mainly seismic resistance considerations. Modifications were made herein to account for wind specific building classes, especially for developing countries.

- According to reference [2], the assignment of relative building classes in each country or region and in each use group corresponds to the classification proposed in reference [6] which do not exactly correspond to building classes from references [3, 4].

Table 2 presents the building classes used for the global assessment and their corresponding basic parameters, including the design level considered in each case. 
According to the previous methodological approach, a general parameter assessment is required to calculate seismic and wind vulnerability functions. To complete the catalog required in risk assessment studies, it is necessary to estimate parameters for new building classes for which vulnerability functions are still not available, especially for those representative of developing countries. In some other cases, parameters have to be estimated for different design levels of previously defined building classes.

Experimental information, analytical models, observed behavior of specific building classes subjected to different hazard levels and expert opinion were used as strategies to complete the required parameters. References $[4,19,23,24,25,26,27,28,29,30,31,32,33,34,35]$ are illustrative of the type of information available to complete the required parameters for specific building classes such as tilt-up walls, confined masonry, unreinforced masonry, warehouses, adobe and mud walls.

\section{Table 2}

Building classes and general characteristics

Note: $\mathrm{H}=$ High, $\mathrm{M}=$ Medium, $\mathrm{L}=$ Low, $\mathrm{P}=$ Poor; " $\mathrm{X}$ " refers to the design levels which were considered in each case to generate a particular vulnerability function. All vulnerability functions are presented in reference [2].

\section{Results}

\subsection{Seismic vulnerability functions}

All the vulnerability functions developed in this paper were calculated using the abovementioned methodological approach. Fig. 3 presents a comparison of some representative seismic vulnerability functions developed for building classes such as adobe (AD1L), unreinforced masonry (URML), reinforced masonry (RM1L), low-rise reinforced concrete frames (C1L) and low-rise steel frames (S1L). Fig. 4 illustrates the variation in the developed vulnerability functions considering different design levels for two different representative building classes: reinforced masonry and reinforced concrete frames. The complete set of seismic vulnerability functions used for GAR 2013 is reported in [2].

Fig. 3. Seismic vulnerability functions for different building classes (design level: M) Note: for legends, see Table 2, Building class ID

Fig. 4. Seismic vulnerability functions for different design levels of selected building classes

\subsection{Wind vulnerability functions}

All the vulnerability functions developed in this paper were calculated using the abovementioned methodological approach. Fig. 5 and Fig. 6 illustrate some representative wind vulnerability functions 
developed for selected building classes. The complete set of wind vulnerability functions used for GAR 2013 are reported in [2].

Fig. 5. Representative wind vulnerability functions for different building classes

Fig. 6. Representative wind vulnerability functions for different design levels

\subsection{Assigning vulnerability functions to building classes}

The assignment process of vulnerability functions to the building classes corresponding to particular regions or countries worldwide involves the assessment of the local quality of construction and compliance with the construction code requirements, for both the seismic and the wind hazards. The following variables and criteria are considered to assign a particular design level to each geographical location:

- Building class and height: building classes which require more specialized engineering skills (reinforced concrete or steel frames as opposed to unreinforced masonry) and tall buildings (with five or more stories) are more likely to have higher design levels than non-engineered low rise buildings (wooden, adobe, and unreinforced masonry buildings).

- Country development level: the classification used in the analysis follows the World Bank country classification, [36, 37] using the following development levels: $\mathrm{H}=$ High, $\mathrm{MH}=$ Medium-High, $\mathrm{ML}=$ Medium-Low, $\mathrm{L}=$ Low.

- The complexity level of the city or town: it is usually associated with the size of the urban hub. High complexity cities usually boast more demanding regulatory agencies and therefore better compliance with construction code levels can be expected. The complexity level classification for each urban hub was made according to $[2,38]$ in the following categories: $\mathrm{H}=\mathrm{High}, \mathrm{M}=$ Medium, $\mathrm{L}=$ Low.

- The regional hazard level: regions with relatively high frequency of medium or high intensity events are more likely to have better construction quality and higher design levels. The regional hazard level was assigned according to the parameters indicated in Table 3 obtained from the global hazard models [2].

Table 3

Seismic and wind hazard levels

In order to perform a rigorous assignment process, specific vulnerability information of the different building classes would be required in a regional basis. To overcome this limitation, an assignment methodology based on expert opinions was adopted, which enabled obtaining a consistent and reasonable set of results in terms of vulnerability variations, according to the main variables under study. Table 4 illustrates a suggested design level assignment process for representative building classes. The complete table is available in Annex 16 of references [2]. 
Table 4

Illustrative suggested design level assignment for some building classes

Note: the complete table is available in Annex 16 of reference [2].

\section{Discussion and conclusions}

A general methodology and a set of seismic and cyclonic wind vulnerability curves suitable for a probabilistic global risk assessment are proposed. They have been estimated for each one of the building classes defined in typical global exposure databases. They also consider possible variations according to the design level in different regions of the world which accounts for the expected quality of construction and design code compliance level. The proposed set of vulnerability functions were used for the probabilistic global risk assessment made in the framework of the UNISDR's Global Assessment Report on Disaster Risk Reduction, GAR 2013 [1, 2].

The vulnerability assessment process considers the resolution, information and limitations established for both the hazard and exposure models adopted for the global risk assessment. The elastic spectral acceleration for 5\% damping and the maximum wind velocities sustained for five (5) seconds were selected as the controlling hazard intensity parameters. A methodological approach based on the Hazus probabilistic risk assessment model was adopted $[6,20]$. Additional considerations and parameters were included to account for additional building classes and different design levels.

A consistent, expert opinion based, methodology is proposed in order to assign vulnerability functions to particular building classes considering the development level of each country, the city complexity level and the hazard level of the region.

The proposed vulnerability assessment approach is consistent with the general goals established for the global risk assessment. Modeling is aimed at capturing only the general vulnerability characteristics at a regional level compatible with the level of resolution used in the exposure database for purposes of obtaining regional relative risk figures. No specific considerations have been made for any particular country, structural system or particular building. The probabilistic approach adopted in the present case allows considering the great uncertainties associated with the vulnerability assessment. It is a main concern to involve in the analysis the controlling conceptual variables that can affect both the vulnerability function itself and the assignment process, although the treatment of those variables may involve great uncertainties. The vulnerability functions described in this paper have been developed solely for the scope of this project and should not be used for purposes other than the ones set forth herein. In the proposed form, they are to be used only under the risk assessment methodology adopted by the CAPRA platform [7] or by consistent methodologies.

Considering the technical framework under which the presented vulnerability functions catalog was developed, it is possible to develop a more detailed vulnerability assessment at regional or country level. The same basic probabilistic assessment approach can be used to obtain more reliable risk figures and down-scale the proposed global model to a particular region under analysis using the same basic principles and arithmetic for the risk assessment process. 


\section{References}

[1] UNISDR. GAR13: Global Assessment Report on Disaster Risk Reduction. ISDR, United Nations. Geneva, Switzerland, 2013.

[2] CIMNE (Centro Internacional de Métodos Numéricos en Ingeniería) et al. Probabilistic Modeling of Natural Risks at the Global Level: Global Risk Model. Background Paper prepared for the 2013 Global Assessment Report on Disaster Risk Reduction. Geneva, Switzerland, 2013. Available at: www.preventionweb.net/english/hyogo/gar/2013/en/bgdocs/CIMNE\%20et.al.\%202013a.pdf

[3] BRZEV, S., GREENE, M., ARNOLD, C., BlOndet, M., CHERrY, S., COMARTin, C., D'AYALA, D., et al. The Web-Based World Housing Encyclopedia: Housing Construction in High Seismic Risk Areas of the World (Vol. paper 1677). Presented at the 13th World Conference on Earthquake Engineering, Vancouver, B.C., Canada, 2004.

[4] Jaiswal, K., Wald, D., \& Porter, K., A Global Building Inventory for Earthquake Loss Estimation and Risk Management. Earthquake Spectra, 26(3), 731. doi:10.1193/1.3450316, 2010.

[5] ORNL., LandScanTM global population distribution data (Raster dataset). US: Oak Ridge National Laboratory, U.S. Department of Energy. Retrieved from http://www.ornl.gov/sci/landscan/index.shtml, 2007.

[6] WAPMERR (World Agency for Planetary Monitoring and Earthquake Risk Reduction). Approximate model for worldwide building stock in three size categories of settlements. Background Paper prepared for the 2013 Global Assessment Report on Disaster Risk Reduction. Geneva, Switzerland, 2013. Available at: www.preventionweb.net/gar

[7] Federal Emergency Management Agency FEMA, Multi-hazard Loss Estimation Methodology. Earthquake Model. HAZUS-MH 2.1, Technical Manual, Washington D.C., United States of America: Federal Emergency Management Agency and National Institute of Building Sciences. , 2011.

[8] ERN-AL Evaluación de Riesgos Naturales - América Latina (2009a). CAPRA: Comprehensive Approach for Probabilistic Risk Assessment. The World Bank, IDB, UN-ISDR, CEPREDENAC. Informe ERN-CAPRA-T1-3 - Modelos de Evaluación de Amenazas Naturales. Junio, 2009. Available at: www.ecapra.org.

[9] Cardona, O.; Ordaz, M.; Arámbula, S.; Yamín, L.; Mahul O., and Ghesquiere, F. Detailed earthquake loss estimation model for comprehensive risk management. First European Conference on Earthquake Engineering and Seismology. Paper Number: 724., 2006. 
[10] UNDRO. Natural Disasters and Vulnerability Analysis. Geneva, Switzerland: UN Disaster Relief., 1980.

[11] Yamin, L, Ghesquiere, F., Cardona, O., Ordaz, M., Modelación probabilista para la gestión del riesgo de desastre, El caso de Bogotá Colombia, Banco Mundial, Universidad de los Andes, 2013.

[12] M. C. Marulanda , M. L. Carreño O. D. Cardona , M. G. Ordaz and A. H. Barbat, "Probabilistic earthquake risk assessment using CAPRA. Application to the city of Barcelona, Spain", Natural Hazards, 69(1), 2013, 59-84.

[13] C. A. Velásquez, O. D. Cardona, M. G. Mora, L. E. Yamin, M. L. Carreño and A. H. Barbat, "Hybrid loss exceedance curve (HLEC) for disaster risk assessment", Natural Hazards, DOI 10.1007/s11069-013-1017-z.

[14] Porter K., Kiremidjian A., Assembly based vulnerability of buildings and its uses in seismic performance evaluation and risk-managemente decision making, Ph.D. Dissertation, Department of Civil and Environmental Engineering, Stanford University, California., 2001.

[15] A. H. Barbat, L. G. Pujades, N. Lantada and R. Moreno, "Performance of buildings under earthquakes in Barcelona, Spain", Computer-Aided Civil and Infrastructure Engineering, 21, 2006, 573-593.

[16] A. H. Barbat, M. L. Carreño, L. G. Pujades, N. Lantada, O. D. Cardona and M. C. Marulanda, "Seismic vulnerability and risk evaluation methods for urban areas. A review with application to a pilot area", Structure and Infrastructure Engineering, 6, 1-2, 2010, 17-38.

[17] A. H. Barbat, M. L. Carreño, O. D. Cardona y M. C. Marulanda, "Evaluación holística del riesgo sísmico en zonas urbanas", Revista internacional de métodos numéricos para cálculo y diseño en ingeniería, 27(1), 2011, 3-27.

[18] Mario Ordaz, Instituto de Ingeniería, Universidad Nacional Autónoma de México, México, personal communication.

[19] Yamin L., Hurtado A., Barbat A., Bernal G., Cardona O., "Earthquake Vulnerability Assessment of Buildings for Catastrophic Risk Analysis in Urban Areas". 15th World Conference Earthquake Engineering, paper 2364, 15WCEE, Lisboa, Portugal, 2012.

[20] Miranda, E., Approximate Seismic Lateral Deformation Demands in Multistory Buildings. J. Struct. Eng., Vol 125 No 4, 417-425., 1999.

[21] Federal Emergency Management Agency FEMA, Multi-hazard Loss Estimation Methodology. Hurricane Model. HAZUS-MH 2.1, Technical Manual, Washington D.C., United States of 
America: Federal Emergency Management Agency and National Institute of Building Sciences, 2011.

[22] Applied Technology Council, "Earthquake Damage Evaluation Data for California", ATC-13, Redwood City, CA, 1985.

[23] Asociación de Ingeniería Sísmica AIS, Fondo de Reconstrucción del Eje Cafetero FOREC, Departamento de Prevención y Atención de Emergencias DPAE, Yamin L, Cardona O, Merlano S, Blandon C, Mejia L, Arango J,Gómez C, Manual de Construcción, Evaluación y Rehabilitación Sismorresistente de Viviendas de Mamposteria, AIS, Bogotá, Colombia, 2005

[24] Corporación la Candelaria - Uniandes (Yamin L, y otros), Cartilla para la Rehabilitación de Viviendas Construidas en Adobe y Tapia Pisada, Corporación La Candelaria Bogotá, Colombia, 2003.

[25] Correal J, Ramirez F, Yamin L, Experimental study of glue laminated guadua as building material: Adhesive Calibration, 8th World Bamboo Congress, Bangkok, China, 2009.

[26] Correal J, Yamin L, Ramírez F, Saavedra F., (2009), Manual de Diseño y Construcción en Paneles Alveolares en Concreto Pretensado, Universidad de los Andes-CIMOC, Bogotá, Colombia, 2009.

[27] Correal J., Yamin L., Rámirez F., González S. Manual de Diseño y Construcción en Guadua Rolliza, Universidad de los Andes-CIMOC, Bogotá, Colombia, 2011.

[28] García L, Yamin L., A Review Of Masonry Construction In Colombia, American Concrete Institute, ACI, SP 147. 1994.

[29] Hurtado, J., Vargas, Y., Pujades, L. and Barbat, A., Evaluación probabilista de la capacidad, fragilidad y daño sísmico en edificios de hormigón armado. Universidad Politécnica de Cataluña. Barcelona, España, 2012.

[30] Meli R, Svetlana B, Yamin L, Astroza M, Boen T, Crisafulli F, Dai J, Farsi M, Hart T, Mebarki A, Moghadam A, Quiun D, Tomazevic M, Seismic Design Guide for Low Rise Confined Masonry Buildings - World housing Encyclopedia, EERI \& IAEE, Confined masonry Network, World Housing Enciclopedia, EERI, IAEE, RMS, Washington DC, USA, 2010.

[31] Yamin L, Reyes J, Phillips C, Ruiz D, Seismic Behavior And Rehabilitation Alternatives for Adobe And Rammed Earth Construction, 13th World Conference on Earthquake Engineering, paper 2840, 13WCEE, Vancouver, Canada, 2004.

[32] Yamin, L., Comportamiento Sísmico de Muros de Mampostería Confinada, Asociación Colombiana de Ingeniería Sísmica, AIS, Boletín Técnico No.45, Bogotá, Colombia, 1994. 
[33] IBHS (Insurance Institute for Business \& Home Safety). High Wind Demonstration Highlights Ways to Improve Commercial Building Performance with Relatively Low-Cost Mitigation Measures. Commercial Wind Test Summary, 2012. Available at: http://www.disastersafety.org/studies-reports/2012-commercial-wind-test-summary/

[34] Vasquez, J.L. "Development of a Windspeed-Damage Correlation Model for Manufactured Housing Subjected to Extreme Winds,” M.S. Thesis, Louisiana State University and Agricultural and Mechanical College, December, 1994.

[35] Sparks, P.R., S.D. Schiff and T.A. Reinhold. "Wind Damage to Envelopes of Houses and Consequent Insurance Losses," Journal of Wind Engineering and Industrial Aerodynamics, Volume 53, pp. 145-155., 1994.

[36] World Bank. Where is the Wealth of Nations? Washington, D.C.: World Bank, 2006

[37] World Bank, World Development Indicators (p. 460). Washington, D.C.: World Bank, 2011

[38] Satterthwaite, D. Outside the Large Cities; The demographic importance of small urban centres and large villages in Africa, Asia and Latin America. Human Settlements, 2006 Working Paper Series Urban Change No. 3. IIED, London. 
Table 1

Design levels for vulnerability assessment

Design Level Description

High $(\mathrm{H}) \quad$ Good quality of construction which fully complies with the earthquake or wind resistance requirements of representative international building codes for high hazard zones.

Moderate (M) Good quality of construction complying with earthquake or wind resistance requirements for intermediate hazard zones.

Low (L) Minimum basic quality of constructions not designed for earthquake or wind

Poor (P) Low quality of construction with no earthquake or wind resistance requirements. 
Table 2

Building classes and general characteristic

\begin{tabular}{|c|c|c|c|c|c|c|c|c|c|c|c|}
\hline \multirow{3}{*}{ No. } & \multirow{3}{*}{$\begin{array}{l}\text { Building Class } \\
\text { ID }\end{array}$} & \multirow{3}{*}{ Description } & \multicolumn{4}{|c|}{ Height } & \multirow{3}{*}{$\begin{array}{l}\text { Structural } \\
\text { Period Te } \\
\text { (s) }\end{array}$} & \multirow{2}{*}{\multicolumn{4}{|c|}{ DESIGN LEVEL }} \\
\hline & & & \multicolumn{2}{|c|}{ Range } & \multicolumn{2}{|c|}{ Typical } & & & & & \\
\hline & & & Name & Stories & Stories & Height (m) & & $\mathbf{H}$ & $\mathbf{M}$ & $\mathbf{L}$ & $\mathbf{P}$ \\
\hline 1 & W1 & Wood, light frame $(\leq 450 \mathrm{~m} 2)$ & - & $1-2$ & 1 & 4.3 & 0.35 & $\mathrm{x}$ & $\mathrm{x}$ & $\mathrm{x}$ & $\mathrm{X}$ \\
\hline 2 & W2 & Wood, commercial and industrial $(>450 \mathrm{~m} 2)$ & - & All & 2 & 7.3 & 0.40 & $\mathrm{X}$ & $\mathrm{x}$ & $\mathrm{x}$ & $\mathrm{X}$ \\
\hline 3 & S1L & & Low-Rise & $1-3$ & 2 & 7.3 & 0.50 & $\mathrm{x}$ & $\mathrm{x}$ & $\mathrm{x}$ & $\mathrm{x}$ \\
\hline 4 & S1M & Steel moment frame & Mid-Rise & 4-7 & 5 & 18.3 & 1.08 & $\mathrm{X}$ & $\mathrm{X}$ & $\mathrm{x}$ & $\mathrm{X}$ \\
\hline 5 & $\mathrm{~S} 1 \mathrm{H}$ & & High-Rise & $8+$ & 13 & 47.5 & 2.21 & $\mathrm{X}$ & $\mathrm{x}$ & $\mathrm{x}$ & $\mathrm{X}$ \\
\hline 6 & S2L & & Low-Rise & $1-3$ & 2 & 7.3 & 0.40 & $\mathrm{x}$ & $\mathrm{X}$ & $\mathrm{x}$ & $\mathrm{X}$ \\
\hline 7 & $\mathrm{~S} 2 \mathrm{M}$ & Steel braced frame & Mid-Rise & 4-7 & 5 & 18.3 & 0.86 & $\mathrm{X}$ & $\mathrm{X}$ & $\mathrm{x}$ & $\mathrm{X}$ \\
\hline 8 & $\mathrm{~S} 2 \mathrm{H}$ & & High-Rise & $8+$ & 13 & 47.5 & 1.77 & $\mathrm{X}$ & $\mathrm{x}$ & $\mathrm{x}$ & $\mathrm{X}$ \\
\hline 9 & S3 & Steel light frame & - & All & 1 & 4.6 & 0.40 & $\mathrm{X}$ & $\mathrm{X}$ & $\mathrm{x}$ & $\mathrm{X}$ \\
\hline 10 & S4L & & Low-Rise & $1-3$ & 2 & 7.3 & 0.35 & $\mathrm{x}$ & $\mathrm{x}$ & $\mathrm{x}$ & $\mathrm{x}$ \\
\hline 11 & S4M & Steel frame with cast-in-place concrete shear walls & Mid-Rise & $4-7$ & 5 & 18.3 & 0.65 & $\mathrm{X}$ & $\mathrm{x}$ & $\mathrm{x}$ & $\mathrm{X}$ \\
\hline 12 & $\mathrm{~S} 4 \mathrm{H}$ & & High-Rise & $8+$ & 13 & 47.5 & 1.32 & $\mathrm{X}$ & $\mathrm{x}$ & $\mathrm{x}$ & $\mathrm{X}$ \\
\hline 13 & S5L & & Low-Rise & $1-3$ & 2 & 7.3 & 0.35 & $\mathrm{x}$ & $\mathrm{x}$ & $\mathrm{x}$ & $\mathrm{X}$ \\
\hline 14 & $\mathrm{~S} 5 \mathrm{M}$ & Steel frame with unreinforced masonry infill walls & Mid-Rise & $4-7$ & 5 & 18.3 & 0.65 & $\mathrm{X}$ & $\mathrm{x}$ & $\mathrm{x}$ & $\mathrm{X}$ \\
\hline 15 & $\mathrm{~S} 5 \mathrm{H}$ & & High-Rise & $8+$ & 13 & 47.5 & 1.32 & $\mathrm{X}$ & $\mathrm{x}$ & $\mathrm{x}$ & $\mathrm{X}$ \\
\hline 16 & $\mathrm{C} 1 \mathrm{~L}$ & & Low-Rise & $1-3$ & 2 & 6.1 & 0.40 & $\mathrm{x}$ & $\mathrm{X}$ & $\mathrm{x}$ & $\mathrm{X}$ \\
\hline 17 & $\mathrm{C} 1 \mathrm{M}$ & Concrete moment frames & Mid-Rise & $4-7$ & 5 & 15.2 & 0.75 & $\mathrm{X}$ & $\mathrm{x}$ & $\mathrm{x}$ & $\mathrm{X}$ \\
\hline 18 & $\mathrm{C} 1 \mathrm{H}$ & & High-Rise & $8+$ & 12 & 36.6 & 1.45 & $\mathrm{X}$ & $\mathrm{x}$ & $\mathrm{x}$ & $\mathrm{X}$ \\
\hline 19 & $\mathrm{C} 2 \mathrm{~L}$ & & Low-Rise & $1-3$ & 2 & 6.1 & 0.35 & $\mathrm{X}$ & $\mathrm{x}$ & $\mathrm{x}$ & $\mathrm{X}$ \\
\hline 20 & $\mathrm{C} 2 \mathrm{M}$ & Concrete shear walls & Mid-Rise & $4-7$ & 5 & 15.2 & 0.56 & $\mathrm{X}$ & $\mathrm{x}$ & $\mathrm{x}$ & $\mathrm{X}$ \\
\hline 21 & $\mathrm{C} 2 \mathrm{H}$ & & High-Rise & $8+$ & 12 & 36.6 & 1.09 & $\mathrm{X}$ & $\mathrm{x}$ & $\mathrm{x}$ & $\mathrm{X}$ \\
\hline 22 & $\mathrm{C} 3 \mathrm{~L}$ & & Low-Rise & $1-3$ & 2 & 6.1 & 0.35 & $\mathrm{X}$ & $\mathrm{X}$ & $\mathrm{x}$ & $\mathrm{X}$ \\
\hline 23 & $\mathrm{C} 3 \mathrm{M}$ & Concrete frame with unreinforced masonry infill & Mid-Rise & $4-7$ & 5 & 15.2 & 0.56 & $\mathrm{x}$ & $\mathrm{x}$ & $\mathrm{X}$ & $\mathrm{x}$ \\
\hline 24 & $\mathrm{C} 3 \mathrm{H}$ & & High-Rise & $8+$ & 12 & 36.6 & 1.09 & $\mathrm{x}$ & $\mathrm{x}$ & $\mathrm{X}$ & $\mathrm{X}$ \\
\hline 39 & $\mathrm{C} 4 \mathrm{~L}$ & & Low-Rise & $1-3$ & 2 & 6.1 & 0.35 & $\mathrm{X}$ & $\mathrm{x}$ & $\mathrm{X}$ & $\mathrm{X}$ \\
\hline 40 & $\mathrm{C} 4 \mathrm{M}$ & Reinforced concrete frames and concrete shear walls & Mid-Rise & $4-7$ & 5 & 15.2 & 0.56 & $\mathrm{x}$ & $\mathrm{x}$ & $\mathrm{X}$ & $\mathrm{X}$ \\
\hline 41 & $\mathrm{C} 4 \mathrm{H}$ & & High-Rise & $8+$ & 12 & 36.6 & 1.09 & $\mathrm{X}$ & $\mathrm{x}$ & $\mathrm{X}$ & $\mathrm{X}$ \\
\hline 44 & $\mathrm{C} 5 \mathrm{~L}$ & & Low-Rise & $1-3$ & 2 & 6.1 & 0.40 & $\mathrm{x}$ & $\mathrm{x}$ & $\mathrm{X}$ & $\mathrm{x}$ \\
\hline 45 & $\mathrm{C} 5 \mathrm{M}$ & Flat slab structure & Mid-Rise & 4-7 & 5 & 15.2 & 0.75 & $\mathrm{X}$ & $\mathrm{X}$ & $\mathrm{X}$ & $\mathrm{X}$ \\
\hline 46 & $\mathrm{C} 5 \mathrm{H}$ & & High-Rise & $8+$ & 12 & 36.6 & 1.45 & $\mathrm{X}$ & $\mathrm{X}$ & $\mathrm{X}$ & $\mathrm{X}$ \\
\hline 25 & PC1L & & Low-Rise & $1-3$ & 1 & 4.6 & 0.35 & $\mathrm{X}$ & $\mathrm{x}$ & $\mathrm{x}$ & $\mathrm{X}$ \\
\hline 42 & PC1M & Precast concrete tilt-up walls & Mid-Rise & 4-7 & 5 & 15.2 & 0.56 & $\mathrm{X}$ & $\mathrm{x}$ & $\mathrm{X}$ & $\mathrm{X}$ \\
\hline 43 & $\mathrm{PC} 1 \mathrm{H}$ & & High-Rise & $8+$ & 12 & 36.6 & 1.09 & $\mathrm{X}$ & $\mathrm{X}$ & $\mathrm{X}$ & $\mathrm{X}$ \\
\hline 26 & PC2L & & Low-Rise & $1-3$ & 2 & 6.1 & 0.35 & $\mathrm{x}$ & $\mathrm{x}$ & $\mathrm{X}$ & $\mathrm{x}$ \\
\hline 27 & $\mathrm{PC} 2 \mathrm{M}$ & Precast concrete frames with concrete shear walls & Mid-Rise & 4-7 & 5 & 15.2 & 0.56 & $\mathrm{X}$ & $\mathrm{x}$ & $\mathrm{X}$ & $\mathrm{X}$ \\
\hline 28 & $\mathrm{PC} 2 \mathrm{H}$ & & High-Rise & $8+$ & 12 & 36.6 & 1.09 & $\mathrm{X}$ & $\mathrm{x}$ & $\mathrm{X}$ & $\mathrm{X}$ \\
\hline 47 & SC1L & $\begin{array}{l}\text { Reinforced concrete frames and steel truss girder } \\
\text { (warehouses) }\end{array}$ & - & All & 1 & 4.6 & 0.32 & $\mathrm{X}$ & $\mathrm{x}$ & $\mathrm{x}$ & $\mathrm{X}$ \\
\hline 29 & RM1L & Reinforced masonry bearing walls with wood or & Low-Rise & $1-3$ & 2 & 6.1 & 0.35 & $\mathrm{X}$ & $\mathrm{x}$ & $\mathrm{X}$ & $\mathrm{X}$ \\
\hline 30 & RM1M & metal deck diaphragms & Mid-Rise & $4+$ & 5 & 15.2 & 0.56 & $\mathrm{X}$ & $\mathrm{x}$ & $\mathrm{x}$ & $\mathrm{x}$ \\
\hline 31 & RM2L & & Low-Rise & $1-3$ & 2 & 6.1 & 0.35 & $\mathrm{x}$ & $\mathrm{X}$ & $\mathrm{X}$ & $\mathrm{X}$ \\
\hline 32 & RM2M & $\begin{array}{l}\text { Reinforced masonry bearing walls with precast } \\
\text { concrete diaphragms }\end{array}$ & Mid-Rise & $4-7$ & 5 & 15.2 & 0.56 & $\mathrm{x}$ & $\mathrm{x}$ & $\mathrm{X}$ & $\mathrm{x}$ \\
\hline 33 & RM2H & & High-Rise & $8+$ & 12 & 36.6 & 1.09 & $\mathrm{X}$ & $\mathrm{X}$ & $\mathrm{X}$ & $\mathrm{X}$ \\
\hline 34 & URML & Unreinforced masonry hearing walls & Low-Rise & $1-2$ & 1 & 4.6 & 0.35 & - & $\mathrm{x}$ & $\mathrm{X}$ & $\mathrm{X}$ \\
\hline 35 & URMM & & Mid-Rise & $3+$ & 3 & 10.7 & 0.50 & - & $\mathrm{x}$ & $\mathrm{X}$ & $\mathrm{X}$ \\
\hline 38 & CM1L & Confined masonry walls & Low-Rise & $1-3$ & 3 & 9.1 & 0.40 & - & $\mathrm{x}$ & $\mathrm{X}$ & $\mathrm{x}$ \\
\hline 36 & AD1L & Adobe & Low-Rise & $1-2$ & 2 & 6.1 & 0.50 & - & $\mathrm{X}$ & $\mathrm{x}$ & $\mathrm{X}$ \\
\hline 37 & TA1L & Tapia & Low-Rise & $1-2$ & 2 & 6.1 & 0.50 & - & $\mathrm{X}$ & $\mathrm{X}$ & $\mathrm{X}$ \\
\hline
\end{tabular}

Note: $\mathrm{H}=$ High, $\mathrm{M}=$ Medium, $\mathrm{L}=$ Low, $\mathrm{P}=$ Poor; "X" refers to the design levels which were considered in each case to generate a particular vulnerability functions. All vulnerability functions are given in reference [2]. 
Table 3

Seismic and wind hazard levels

\begin{tabular}{ccc}
\hline Hazard level & $\begin{array}{c}\text { Maximum ground acceleration } \\
\text { (g) }\end{array}$ & $\begin{array}{c}\text { Maximum wind velocity } \\
\text { (kph) }\end{array}$ \\
\hline \hline Low (L) & $<0.10$ & $<150$ \\
Medium (M) & $0.10-0.25$ & $150-300$ \\
High (H) & $>0.25$ & $>300$ \\
\hline
\end{tabular}

Table 4

Illustrative suggested design level assignment for some building classes

\begin{tabular}{|c|c|c|c|c|c|c|c|c|c|c|c|c|c|c|c|c|c|c|c|}
\hline \multirow{6}{*}{ 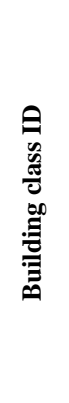 } & \multirow{6}{*}{ Building class description } & \multicolumn{18}{|c|}{ Country Development Level } \\
\hline & & \multicolumn{9}{|c|}{ High } & \multicolumn{9}{|c|}{ Low } \\
\hline & & \multicolumn{9}{|c|}{ Complexity level of the city } & \multicolumn{9}{|c|}{ Complexity level of the city } \\
\hline & & \multicolumn{3}{|c|}{ High } & \multicolumn{3}{|c|}{ Medium } & \multicolumn{3}{|c|}{ Low } & \multicolumn{3}{|c|}{ High } & \multicolumn{3}{|c|}{ Medium } & \multicolumn{3}{|c|}{ Low } \\
\hline & & \multicolumn{3}{|c|}{ Hazard Level } & \multicolumn{3}{|c|}{ Hazard Level } & \multicolumn{3}{|c|}{ Hazard Level } & \multicolumn{3}{|c|}{ Hazard Level } & \multicolumn{3}{|c|}{ Hazard Level } & \multicolumn{3}{|c|}{ Hazard Level } \\
\hline & & 司 & 声 & ב3. & : & 当 & 芆 & 할 & 䒠 & ב⿱ & 总 & 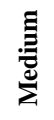 & 宐 & 호요 & 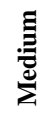 & فَత & 总 & 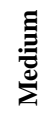 & 3 \\
\hline $\mathrm{C} 1 \mathrm{~L}$ & Concrete moment frames low-rise & $\mathrm{H}$ & M & M & $\mathrm{H}$ & M & $\mathrm{M}$ & $\mathrm{H}$ & M & M & M & M & $\mathrm{M}$ & M & M & $\mathrm{L}$ & $\mathrm{L}$ & $\mathrm{L}$ & $\mathrm{L}$ \\
\hline $\mathrm{C} 1 \mathrm{M}$ & Concrete moment frames mid-rise & $\mathrm{H}$ & M & M & $\mathrm{H}$ & M & M & $\mathrm{H}$ & M & M & $\mathrm{H}$ & M & M & M & M & M & M & $\mathrm{L}$ & $\mathrm{L}$ \\
\hline $\mathrm{C} 1 \mathrm{H}$ & Concrete moment frames high-rise & $\mathrm{H}$ & M & M & $\mathrm{H}$ & M & M & $\mathrm{H}$ & M & M & $\mathrm{H}$ & M & M & $\mathrm{H}$ & M & M & $\mathrm{M}$ & M & $\mathrm{M}$ \\
\hline $\mathrm{C} 3 \mathrm{~L}$ & $\begin{array}{l}\text { Concrete frame with unreinforced } \\
\text { masonry infill walls low-rise }\end{array}$ & M & $\mathrm{L}$ & $\mathrm{L}$ & $\mathrm{M}$ & $\mathrm{L}$ & $\mathrm{L}$ & $\mathrm{M}$ & $\mathrm{L}$ & $\mathrm{L}$ & $\mathrm{L}$ & $\mathrm{L}$ & $\mathrm{L}$ & $\mathrm{L}$ & $\mathrm{L}$ & $\mathrm{L}$ & $\mathrm{L}$ & $P$ & $\mathrm{P}$ \\
\hline $\mathrm{C} 3 \mathrm{M}$ & $\begin{array}{l}\text { Concrete frame with unreinforced } \\
\text { masonry infill walls mid-rise }\end{array}$ & M & $\mathrm{L}$ & $\mathrm{L}$ & M & $\mathrm{L}$ & $\mathrm{L}$ & $\mathrm{M}$ & $\mathrm{L}$ & $\mathrm{L}$ & $\mathrm{M}$ & $\mathrm{L}$ & $\mathrm{L}$ & $\mathrm{L}$ & $\mathrm{L}$ & $\mathrm{L}$ & $\mathrm{L}$ & $\mathrm{L}$ & $\mathrm{P}$ \\
\hline $\mathrm{C} 3 \mathrm{H}$ & $\begin{array}{l}\text { Concrete frame with unreinforced } \\
\text { masonry infill walls high-rise }\end{array}$ & M & $\mathrm{L}$ & $\mathrm{L}$ & M & $\mathrm{L}$ & $\mathrm{L}$ & $\mathrm{M}$ & $\mathrm{L}$ & $\mathrm{L}$ & $\mathrm{M}$ & $\mathrm{M}$ & $\mathrm{L}$ & M & $\mathrm{L}$ & $\mathrm{L}$ & M & $\mathrm{L}$ & L \\
\hline C4L & $\begin{array}{l}\text { Reinforced concrete frames and } \\
\text { concrete shear walls low-rise }\end{array}$ & $\mathrm{H}$ & $\mathrm{M}$ & M & $\mathrm{H}$ & M & $\mathrm{M}$ & $\mathrm{H}$ & M & M & $\mathrm{L}$ & $\mathrm{L}$ & $\mathrm{L}$ & $\mathrm{L}$ & $\mathrm{L}$ & $\mathrm{P}$ & $\mathrm{L}$ & $\mathrm{P}$ & $\mathrm{P}$ \\
\hline $\mathrm{C} 4 \mathrm{M}$ & $\begin{array}{l}\text { Reinforced concrete frames and } \\
\text { concrete shear walls mid-rise }\end{array}$ & $\mathrm{H}$ & M & M & $\mathrm{H}$ & M & $\mathrm{M}$ & $\mathrm{H}$ & M & M & $\mathrm{M}$ & $\mathrm{L}$ & $\mathrm{L}$ & $\mathrm{L}$ & $\mathrm{L}$ & $\mathrm{L}$ & $\mathrm{L}$ & $\mathrm{P}$ & $\mathrm{P}$ \\
\hline $\mathrm{C} 4 \mathrm{H}$ & $\begin{array}{l}\text { Reinforced concrete frames and } \\
\text { concrete shear walls high-rise }\end{array}$ & $\mathrm{H}$ & M & M & $\mathrm{H}$ & $\mathrm{M}$ & $\mathrm{M}$ & $\mathrm{H}$ & M & M & $\mathrm{M}$ & $\mathrm{M}$ & $\mathrm{L}$ & $\mathrm{M}$ & $\mathrm{L}$ & $\mathrm{L}$ & M & $\mathrm{L}$ & L \\
\hline
\end{tabular}

Note: the complete table is available in Annex 16 of reference [2]. 


\section{Figure list captions}

Fig. 1. Typical representation of fragility (a) and vulnerability (b) formulations

Fig. 2. Main steps to generate vulnerability functions

Fig. 3. Seismic vulnerability functions for different building classes (design level: M)

Fig. 4. Seismic vulnerability functions for different design levels of selected building classes

Fig. 5. Representative wind vulnerability functions for different building classes

Fig. 6. Representative wind vulnerability functions for different design levels 